\title{
Morphological, Molecular and Genomic Characterization of Two Inter-Subspecific Hybrids between Olive Cultivars and Olive Subspecies
}

\author{
Jinhua Li *(D), Xinyue Ji, Zhaoshan Wang, Yanfei Zeng and Jianguo Zhang \\ State Key Laboratory of Forest Genetics and Tree Breeding, Key Laboratory of Tree Breeding and Cultivation of \\ National Forestry and Grassland Administration, Research Institute of Forestry, Chinese Academy of Forestry, \\ Beijing 100091, China; xinyuej137@163.com (X.J.); wangzs@caf.ac.cn (Z.W.); zengyf@caf.ac.cn (Y.Z.); \\ zhangig@caf.ac.cn (J.Z.) \\ * Correspondence: lijinh@caf.ac.cn
}

Citation: Li, J.; Ji, X.; Wang, Z.; Zeng,

Y.; Zhang, J. Morphological,

Molecular and Genomic

Characterization of Two

Inter-Subspecific Hybrids between Olive Cultivars and Olive Subspecies. Horticulturae 2021, 7, 138. https://

doi.org/10.3390/horticulturae7060138

Academic Editor: Juan Capel

Received: 13 April 2021

Accepted: 1 June 2021

Published: 7 June 2021

Publisher's Note: MDPI stays neutral with regard to jurisdictional claims in published maps and institutional affiliations.

Copyright: (c) 2021 by the authors. Licensee MDPI, Basel, Switzerland. This article is an open access article distributed under the terms and conditions of the Creative Commons Attribution (CC BY) license (https:/ / creativecommons.org/licenses/by/ $4.0 /)$.

\begin{abstract}
Two inter-subspecific $F_{1}$ hybrids have been obtained by crossing olive cultivars ('Frantoio' and 'Coratina') with pollen donors from olive subspecies (Olea europaea subsp. cuspidata) to enrich the germplasm of cultivated olive in southern China. This study aimed to investigate the characterization of morphological traits and molecular markers in the two hybrids and their parents of crosses. The morphological study showed a significant difference between genotypes according to the main discriminative parameters on qualitative and quantitative traits of leaf, fruit, and endocarp. A set of six co-dominant polymorphic simple sequence repeats (SSRs) were used for molecular identification, and SSR analysis confirmed that two progenies were the offspring of their cited parents based on the presence of parental specific SSR alleles. Three single-copy nuclear loci (SCNL) primer pairs were used for amplification of single-copy genes in the two progenies and their parents and after then PCR products were sequenced. Sequence alignment analysis on the effective data showed a total of 15 different base sites between two progenies, which were confirmed as true inter-specific hybrids between olive cultivars and subsp. cuspidata.
\end{abstract}

Keywords: inter-subspecific hybrid; morphological characterization; SSR; SCNL; Olea europaea subsp. europaea; Olea europaea subsp. cuspidata

\section{Introduction}

Native to the Mediterranean region, tropical and central Asia, and various parts of Africa, the olive tree (Olea europaea L.) is demonstrated to have originated from Levant in the Middle East, after which several differentiations occurred, the most cited of which was from the East to the West Mediterranean and spread to the surrounding areas from there several millennia ago [1-5]. Cultivated olive (O. europaea L. subsp. Europaea var. europaea; Oleaceae) is the most iconic tree of the Mediterranean Basin (MB) as an economically significant species and a keystone of traditional Mediterranean agriculture [6-8]. Production of olive is mainly concentrated around the $\mathrm{MB}$, where about $90 \%$ of the total olive production in the world occurs. In more modern times, the olive tree has continued to spread outside the MB, and today it is farmed in places as far removed from its origins as southern Africa, Australia, Japan, and China (IOC). A huge number of olive cultivars in all growing areas were yielded from empiric local selection within olives and crosses between previously selected or introduced cultivars and other local cultivars or wild olives [9]. The traditional olive cultivars that are still widely used are selections from the local autochthonous cultivars, which are well adapted to their natural environment. Breeding of new cultivars are now devoted towards developing and selection of new varieties more suitable to modern olive agriculture [10]. The recurrent selection for high production in the original local region filtered potentially valuable genetic variants and associated phenotypes out of olive 
cultivars, ranging from disease and insect resistance to drought tolerance. Wild olive germplasm (O. europaea subsp. europaea var. sylvestris) and olive subspecies (O. europaea subsp. cuspidata) have also been identified as a possible source of tolerance to abiotic stress [11-13]. A wide genetic diversity has been reported for wild olives, which could be particularly interesting for the introgression of some agronomic traits and resistance to biotic and abiotic stresses in breeding programs [14-18]. Crossbreeding between olive cultivars and wild olive with specific characters might represent a useful strategy to exploit the enormous gene pool represented by the wild olive and olive subspecies for plantations in traditional and new olive-growing countries [9,15,19-22].

In China, the olive tree has been introduced and cultivated for more than 50 years in sub-tropical areas with a non-Mediterranean climate. The estimated production of olive oil in China was only 6000 tons, almost 9 times smaller than its total olive oil consumption in 2019-2020 (IOC). It is expected to obtain more productivity of olive trees in suitable growing areas in China, especially in the western provinces of China, such as Gansu, Sichuan, Shaanxi, and Yunnan. Although a few olive clones or cultivars domesticated in the regions are well adapted to their environment, they have often lacked other desired agronomic characteristics and have failed in many cases to respond enough to new cultivation methods. The requirement for new diverse olive cultivars has increased markedly during the last three decades due to the trend of establishing olive industries with environmental adaptation to such adverse agroecological conditions. However, the potential cultivar improvement due to clonal selection is relatively limited as the genetic composition of those selections is basically unchanged or only slightly modified from that of the original cultivar [20]. Exploring the genetic diversity of the large number of well-defined olive cultivars is crucial due to their natural and basic source for creating new cultivars. The potential use of wild olive germplasm and olive subspecies also known as oleasters as a source of genetic variability for important agronomic traits has been suggested, particularly regarding resistance to specific adverse biotic and abiotic environmental conditions $[17,18,21]$. Olive subspecies O. europaea subsp. cuspidata is native to a widespread area from southeast Europe and northeast Africa through southwest Asia to the drier parts of Yunnan and Sichuan in China [22]. It is a plastic species adapted to different climates [22], ranging from semi-arid to meso-humid ones, and shows resistance to fungal diseases [11,23]. In Sichuan and Guangxi in China, the grafted olive trees on the rootstock of Olea europaea subsp. cuspidata showed conspicuous resistance to Pseudomonas solanacearum E. F. and had better suitability to the clayer acidic soil in the subtropical area [24]. The crosses between cultivated olive with wild olives and olive subspecies have been recently reported $[15,19,23]$, with the intention to enlarge the basis of genetic variability for olive breeding [9]. It is confirmed that the two subspecies are crossable and that subsp. cuspidata can be used as genetic resources for the olive and vice versa [11]. Furthermore, comparison and pre-breeding evaluation of the wild olive and olive subspecies progenies obtained by controlled crosses and open pollinations revealed genetic diversity [12,15,25]. In the last few decades, O. europaea subsp. cuspidata has been used for pollen donors in controlled crossing with well-defined olive cultivars as an alternative approach to increase the diversity sources in southern China [26,27]. Progenies have already been obtained by crosses and open-pollinations of cultivars, and their evaluation has been also carried out under field conditions [28,29].

The experimental crosses between several olive cultivars and the wild related subspecies cuspidata as pollen donors were undertaken in Yunan and Sichuan, Southern China in the last two decades. The hybrids of two parental combinations were obtained and tested in the field trial. On account of the preceding information on crossing and evaluation, the aim of this study was to investigate the characterization of morphological traits and molecular markers in the hybrids of crosses between olive cultivars and olive subspecies, O. europaea subsp. cuspidata, representing a wide range of genetic variability and the relationships between them, and to compare and identify genotypes being potentially used as genetic resources. 


\section{Materials and Methods}

\subsection{Plant Materials}

The experimental material used in the present study comprised two $\mathrm{F}_{1}$ hybrids (hereafter named ' $\mathrm{FJ}$ ' and ' $\mathrm{CJ}$ '), obtained through the genetic controlled crossing of two olive cultivars with olive subspecies (O. europaea subsp. cuspidata), and their parents (Table 1 and Figure 1). The two $F_{1}$ hybrids were supposed to be the result of crossing combinations between 'Frantioto' and 'Coratina' as the mother parents with pollen from the olive subspecies (O. europaea subsp. cuspidata) collected in Southern China.

Table 1. Two $F_{1}$ hybrids of olive inter-subspecies and their parents.

\begin{tabular}{ccc}
\hline $\mathbf{F}_{\mathbf{1}}$ Hybrid & Crossing & Collecting Region \\
\hline 'FJ' & 'Frantoio' $\times$ subsp. cuspidata & Yunnan Province, Southern China \\
'CJ' & 'Coratina' $\times$ subsp. cuspidata & Sichuan Province, Southern China \\
\hline
\end{tabular}

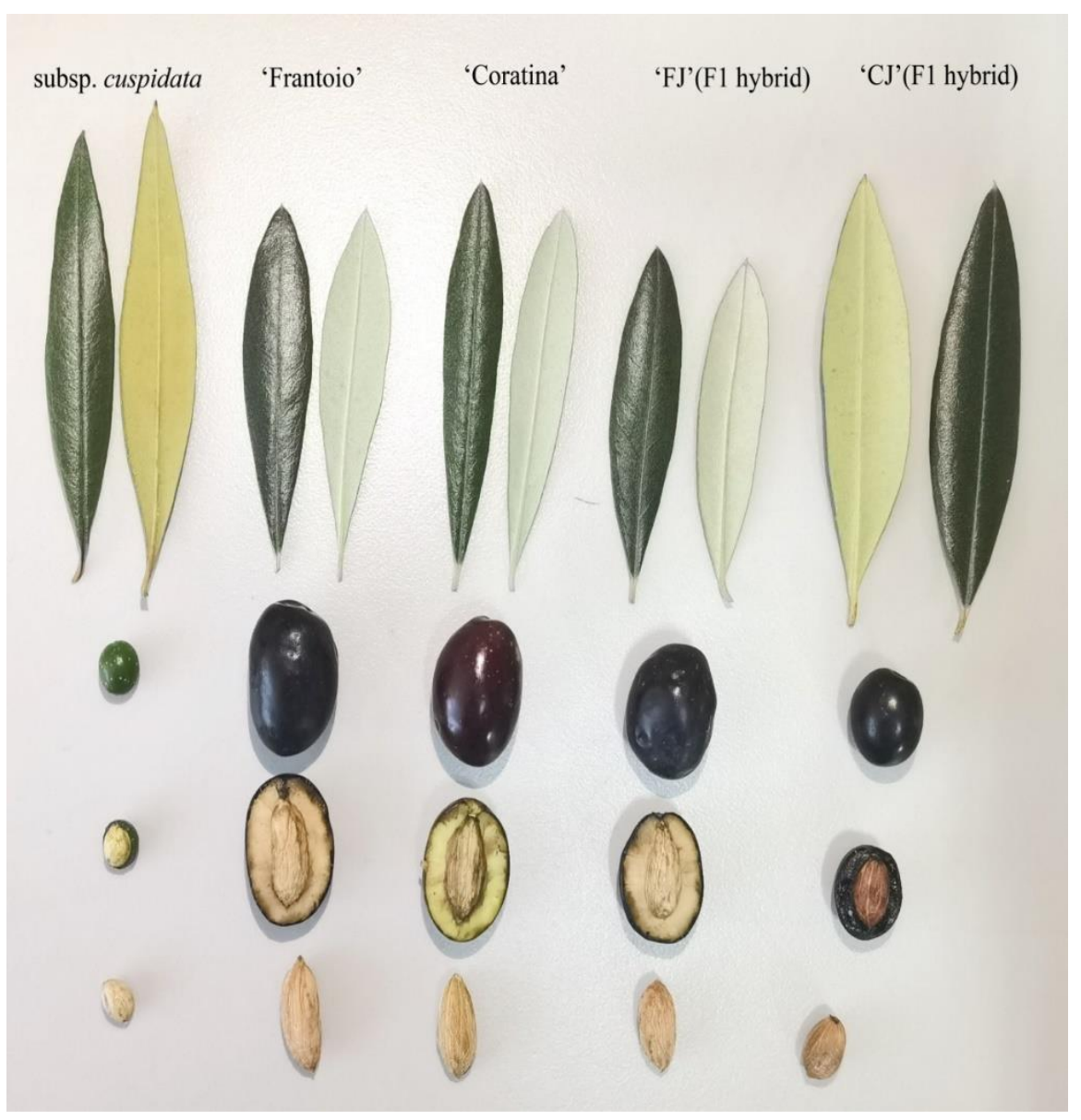

Figure 1. Morphological characters of leaf, fruit and endocarp for O. europaea subsp. cuspidata, 'Frantoio', 'Coratina', 'FJ' and 'CJ' from left to right in the line.

\subsection{Morphological Characterization}

Morphological description was performed according to the methodology for primary characterization on leaf, fruit and endocarp in the World Catalogue of Olive Varieties published by IOC [30], including four leaf characteristics (length, width, shape and layer color of scales below), five fruit characteristics (length, width, shape, apex and base), and seven endocarp characteristics (length, width, shape, apex, base, number of grooves and tip of apex) (Table 2). 
Table 2. Ten qualitative traits of morphological characteristics in two olive hybrid progenies and their parents.

\begin{tabular}{|c|c|c|c|c|c|c|}
\hline \multicolumn{2}{|c|}{ Qualitative Trait } & \multirow{3}{*}{$\begin{array}{c}\begin{array}{c}\text { Subsp. } \\
\text { cuspidata } \\
\left(\sigma^{\top}\right)\end{array} \\
\text { Brown } \\
\text { Lanceolate }\end{array}$} & \multirow{3}{*}{$\begin{array}{c}\text { 'Frantoio' } \\
\text { (ㅇ) }\end{array}$} & \multirow{3}{*}{$\begin{array}{c}\text { 'Coratina' } \\
(\text { (o) }\end{array}$} & \multirow{3}{*}{$\begin{array}{c}\text { 'FJ' } \\
\left(\mathrm{F}_{1} \text { Hybrid) }\right. \\
\text { Silvery-grey } \\
\text { Elliptic- } \\
\text { lanceolate }\end{array}$} & \multirow{3}{*}{$\begin{array}{c}\text { 'CJ' } \\
\left(\mathrm{F}_{\mathbf{1}} \text { Hybrid) }\right. \\
\text { Light brown } \\
\text { Elliptic- } \\
\text { lanceolate }\end{array}$} \\
\hline & Underside color & & & & & \\
\hline Leaf & Shape & & & & & \\
\hline \multirow{3}{*}{ Fruit } & Shape & Spherical & Ovoid & Elongated & Ovoid & Ovoid \\
\hline & Apex & Rounded & Rounded & Rounded & Rounded & Rounded \\
\hline & Base & Rounded & Truncated & Rounded & Truncated & Rounded \\
\hline \multirow{5}{*}{ Endocarp } & Shape & Ovoid & Elliptic & Elongated & Elliptic & Ovoid \\
\hline & Apex & Rounded & Pointed & Pointed & Rounded & Rounded \\
\hline & Base & Rounded & Pointed & Pointed & Rounded & Rounded \\
\hline & $\begin{array}{l}\text { Number of } \\
\text { grooves }\end{array}$ & High & Medium & Medium & High & High \\
\hline & Tip of apex & Without mucro & With mucro & With mucro & Without mucro & Without mucro \\
\hline
\end{tabular}

The morphological investigation included 6 quantitative traits and 10 qualitative traits of morphological characters (Table 3). All the measurements were evaluated for random samples of 40 leaves and fruits from each tree at the height of shoulder from southern side of the canopy. Endocarps were removed and were subject to characterization.

Table 3. Mean and range of six quantitative traits of morphological characteristics in two $\mathrm{F}_{1}$ hybrids and their parents.

\begin{tabular}{|c|c|c|c|c|c|c|}
\hline \multicolumn{2}{|c|}{ Quantitative Trait } & $\begin{array}{c}\text { Subsp. caspidata } \\
\left(\sigma^{2}\right)\end{array}$ & $\begin{array}{l}\text { 'Frantoio' } \\
\text { (ㅇ) }\end{array}$ & $\begin{array}{l}\text { ‘Coratina' } \\
\text { (오 }\end{array}$ & $\begin{array}{c}\text { 'FJ' } \\
\text { (F, Hybrid) }\end{array}$ & $\begin{array}{c}\text { 'CJ' } \\
\text { (F1 Hybrid) }\end{array}$ \\
\hline \multirow{3}{*}{ Leaf } & Length/cm & $7.62(6.66-8.63)$ & $6.43(5-8.9)$ & $6.27(5.1-7.1)$ & $5.29(4.57-6.12)$ & $6.41(4.8-8.1)$ \\
\hline & Width $/ \mathrm{cm}$ & $1.21(0.87-1.51)$ & $1.69(1.28-2.09)$ & $1.32(1.05-1.6)$ & $1.15(0.97-1.42)$ & $1.23(0.9-1.5)$ \\
\hline & Shape index & $6.30(4.41-10.65)$ & $3.86(3.03-5.26)$ & $4.83(3.27-6.38)$ & $4.6(3.22-6.31)$ & $5.21(3.2-9)$ \\
\hline \multirow{3}{*}{ Fruit } & Length/cm & 1.17 & $1.64(1.5-1.9)$ & $1.41(1.3-1.5)$ & 1.55 (1.39-1.7) & $1.54(1.37-1.72)$ \\
\hline & Width/cm & 0.96 & $2.33(2.1-2.9)$ & $2.2(2-2.4)$ & $1.13(1.03-1.25)$ & $1.21(1.07-1.34)$ \\
\hline & Shape index & 1.22 & $1.42(1.11-1.93)$ & $1.56(1.5-1.62)$ & 1.37 (1.24-1.37) & $1.28(1.18-1.45)$ \\
\hline \multirow{3}{*}{ Endocarp } & Length/mm & $7-8$ & $17.5(16-19)$ & $18.3(17-20)$ & $12.82(11.65-14.18)$ & $12.64(11.45-13.9)$ \\
\hline & Width/mm & $5-6$ & $8.36(7.85-9.78)$ & 7.81 (7.58-8) & $7.09(6.54-7.77)$ & $7.48(6.82-8.24)$ \\
\hline & Shape index & $1.17-1.6$ & $2.1(1.84-2.27)$ & $2.34(2.23-2.57)$ & $1.81(1.67-1.93)$ & $1.69(1.58-1.83)$ \\
\hline
\end{tabular}

\subsection{DNA Extraction and Microsatellite Amplification}

Total genomic DNA was extracted from leaves according to the CTAB method with slight modifications [31]. DNA concentration and purity were evaluated by NanoDrop 8000 spectrophotometer (Thermo Scientific, Waltham, MA, USA).

A set of six microsatellite (SSR) primer pairs was used for fingerprinting the progenies and their parents (Table 4). The choice was made based on literature data and the degree of polymorphism, as well as on the clearness and reproducibility of amplified DNA fragments. Three SSRs (DCA3, DCA11 and DCA18) have been developed by Sefc et al. (2000) [32], two (UDO99-11 and UDO99-19) by Cipriani et al. (2002) [33] and one (EMO90) by de la Rosa et al. (2013) [34]. PCR amplifications were carried out in a final volume of $20 \mu \mathrm{L}$ containing $5 \mathrm{ng}$ of DNA, $1.5 \mathrm{mM} \mathrm{MgCl}_{2}, 60 \mu \mathrm{M}$ dNTPs, 1.25 units of Taq DNA polymerase (TaKaRa), $1 \mu \mathrm{M}$ of forward primer labeled with a fluorescent dye (FAM or HEX) and $1 \mu \mathrm{M}$ of reverse primer. SSR amplifications were performed on a thermal cycler (Biometra ${ }^{\circledR}$ ) under the following conditions: initial denaturation at $94{ }^{\circ} \mathrm{C}$ for $5 \mathrm{~min}$, followed by 35 cycles at $94{ }^{\circ} \mathrm{C}$ for $30 \mathrm{~s}$ (denaturation), $\mathrm{Tm}$ for $30 \mathrm{~s}$ (annealing) and $72{ }^{\circ} \mathrm{C}$ for $30 \mathrm{~s}$ (extension), and a final extension at $72{ }^{\circ} \mathrm{C}$ for $7 \mathrm{~min}$. 
Table 4. Primer sequences of six micrositellite loci used in molecular analysis.

\begin{tabular}{|c|c|c|c|}
\hline Source & SSR & Primer Sequence $\left(5^{\prime}-3^{\prime}\right)$ & Repeat Motif \\
\hline \multirow[t]{3}{*}{ Sefc et al., 2000 [32] } & DCA3 & $\begin{array}{c}\text { F- } \\
\text { CCCAAGCGGAGGTGTATATTGTTAC } \\
\text { R- } \\
\text { TGCTTTTGTCGTGTTTGAGATGTTG }\end{array}$ & (GA)19 \\
\hline & DCA11 & $\begin{array}{c}\text { F- } \\
\text { GATCAAACTACTGCACGAGAGAG } \\
\text { R-TTGTCTAGTGAACCCTTAAACC }\end{array}$ & (GA)26(GGGA)4 \\
\hline & DCA18 & $\begin{array}{l}\text { F- } \\
\text { AAGAAAGAAAAAGGCAGAATTAAGC } \\
\text { R- } \\
\text { GTTTTCGTCTCTCTACATAAGTGAC }\end{array}$ & (CA)4CT(CA)3 (GA)19 \\
\hline \multirow[t]{2}{*}{ Cipriani et al., 2002 [33] } & UDO99-11 & $\begin{array}{l}\text { F-TGACTCCCTTTAAACTCATCAGG } \\
\text { R-TGCGCATGTAGATGTGAATATG }\end{array}$ & $\begin{array}{l}(\mathrm{CT}) 7(\mathrm{CA}) 10(\mathrm{CT}) 2(\mathrm{CA}) 2 \\
\text { СТ(CA)2CT(CA)9 }\end{array}$ \\
\hline & UDO99-19 & $\begin{array}{l}\text { F-TCCCTTGTAGCCTCGTCTTG } \\
\text { R-GGCCTGATCATCGATACCTC }\end{array}$ & $(\mathrm{GT}) 20(\mathrm{AT}) 5$ \\
\hline De la Rosa et al., 2013 [34] & EMO90 & $\begin{array}{c}\text { F-CATCCGGATTTCTTGCTTTT } \\
\text { R-AGCGAATGTAGCTTTGCATGT }\end{array}$ & (CA)10 \\
\hline
\end{tabular}

After successful amplification, evaluated by electrophoresis in 1.5\% agarose gel, PCR products were combined with Liz 500 internal size standards and were separated using an automatic capillary sequencer (ABI 3730 Genetic Analyser Applied Biosystems). The fragments were visualized as peaks with the respective size and intensities using Peak Scanner v.1.0 and GeneMapper v.4.0 softwares from Applied Biosystems (Foster City, CA, USA).

\subsection{Parentage Analysis Using SSR Markers}

According to the microsatellite profile, the offspring of each cross was classified as true hybrid or foreign origin. Parentage was analyzed based on the inheritance of one allele at a single SSR locus transmitted from the parent to the offspring. If one maternal and one paternal allele were present for each locus, the progeny was considered a 'true hybrid'. In the case where the parentage was different from that expected, the real parent was estimated $[7,35]$.

\subsection{Genomic DNA Isolation and DNA Sequencing of SCNL}

Total genomic DNA was isolated and purified from leaf tissue $(100 \mathrm{mg})$ using the DNeasy Plant Mini Kit (Tiangen Biotech Beijing, Beijing, China) following the manufacturer's instructions. The DNA precipitate was dissolved in $50 \mu \mathrm{L}$ TE solution and stored at $-20{ }^{\circ} \mathrm{C}$ until use.

A set of primer pairs for single-copy nuclear loci (SCNL) have been developed and screened for the identification of olive cultivars and subsp. cuspidata by Shao (2019) [36]. Three SCNLs (SWH1, SWH5 and SWH6) were used for amplification of single-copy genes in the progenies and their parents (Table 5). PCR amplifications were carried out in a final volume of $25 \mu \mathrm{L}$ containing $5 \mathrm{ng}$ of DNA, $12.5 \mu \mathrm{L}$ PCR mix $(2.5 \mu \mathrm{L} 10 \times$ Buffer solution, $2.5 \mu \mathrm{L}$ dNTPs, 1.25 units of Taq DNA polymerase), $1 \mu \mathrm{M}$ of primer and $1 \mu \mathrm{M}$ of reverse primer. PCR amplifications were performed on a thermal cycler (ABI Veriti96) under the following conditions: initial denaturation at $94{ }^{\circ} \mathrm{C}$ for $4 \mathrm{~min}$, followed by 10 cycles at $94{ }^{\circ} \mathrm{C}$ for $30 \mathrm{~s}$ (denaturation), $60{ }^{\circ} \mathrm{C}$ for $30 \mathrm{~s}$ (annealing) and $72{ }^{\circ} \mathrm{C}$ for $2 \mathrm{~min}$ (extension), and 26 cycles at $94{ }^{\circ} \mathrm{C}$ for $30 \mathrm{~s}$ (denaturation), $55^{\circ} \mathrm{C}$ for $30 \mathrm{~s}$ (annealing) and $72{ }^{\circ} \mathrm{C}$ for $2 \mathrm{~min}$ (extension), and a final extension at $72{ }^{\circ} \mathrm{C}$ for $10 \mathrm{~min}$. After successful amplification, evaluated by electrophoresis in $1.5 \%$ agarose gel, PCR reaction products were analyzed using an automatic imager G-Box (Chemi XX6, Syngene, Karnataka, India). The PCR products were purified and sequenced using Sanger sequencing by TsingKe Company (Beijing, China) in Beijing. 
Table 5. Characteristics of single-copy nuclear loci (SCNL) developed for O. europaea L. used in sequencing analysis.

\begin{tabular}{crcc}
\hline Locus & Primer Sequence $\left(5^{\prime}-\mathbf{3}^{\prime}\right)$ & Tm $\left({ }^{\circ} \mathbf{C}\right)$ & GenBank Accession No. \\
\hline \multirow{2}{*}{ SWH1 } & F-ACTTCATTTTACACCCATTTTTA & 50 & MG725069-MG725089 \\
& R-CACTTGATGCTTTTGTTTCTTTT & MG725153-MG725173 \\
SWH5 & F-CAAGAAAAAACAAAGAAAGAGCA & 52 & MG725174-MG725194 \\
RWH6 & F-GGAAAACTACCTGGGAACAAACC & 58 & \multirow{2}{*}{ R-AGAGGGAGAAAGGGGTAGCAG } \\
\hline
\end{tabular}

\subsection{Data Analysis}

After capillary electrophoresis of SSR primers were considered for alleles and allelic data obtained from GeneMapper V4.0 analysis, peaks in allelic profiles were analyzed using SSR markers for the variation between two $F_{1}$ hybrids and their parents. Contig Express software was used to analyze the peak maps of genome sequences and cut off the $50 \sim 60 \mathrm{bp}$ low-quality sequence sites at both ends of the sequences, and the overlapped sequences were manually collated. Then, BioEdit was used to perform sequence alignment analysis on the effective data.

\section{Results and Discussions}

\subsection{Morphological Characterization of Two Inter-Subspecific Progenies and Their Parents}

The morphological criteria of olive description presented in the World Catalog of Olive Varieties [30] were used to describe two progenies and their parents on a total of sixteen recorded traits, including in quantitative and qualitative characters of leaf, fruit and endocarp. Morphological characteristics of five samples are presented in Table 2 and shown in Figure 1. The results of morphological characterization showed the specific differences between two olive cultivars, 'Frantoio', 'Coratina', and subsp. cuspidata on leaf, fruit and endocarp. The upper surface of the leaves of subsp. cuspidata was less varnished than subsp. europaea, and the lower face was a golden green (sometimes reddish) and not silvered as for subsp. europaea [11]. The endocarp of subsp. cuspidata had an ovoid shape, while that of 'Frantoio' and 'Coratina' were represented as being elliptic and elongated [37].

Between two olive cultivars as mother parents of two $F_{1}$ hybrids, 'Frantoio' was significantly different from 'Coratina' in the shapes of leaf, fruit and endocarp. Two $\mathrm{F}_{1}$ hybrids, ' $\mathrm{FJ}$ ' and ' $\mathrm{CJ}$ ', were very similar in phenotypic traits with the difference for the shapes of fruit base and kernel. Fruit shape, base and endocarp shape of ' $\mathrm{FJ}^{\prime}$ ' were longated, truncated and elliptic, while 'CJ' had ovoid fruit shape, rounded fruit base and ovoid endocarp shape. Comparison of the two hybrids with their mother parents showed that both ' $\mathrm{FJ}$ ' and its mother parent, 'Frantoio', were similiar in fruit base and endocarp shape. In terms of the difference in the shapes of leaf, fruit, endocarp and fruit base, both ' $\mathrm{FJ}$ ' and ' $\mathrm{CJ}$ ' showed similarity with their father parent, subsp. cuspidata, for other traits. In particular, the hybrid 'CJ' was similar with its father parent, subsp. cuspidata, but different for the shapes of leaf and fruit. Moreover, the undersides of the leaves of the mother parent, 'Frantoio' and 'Coratina', and the hybrid ' $\mathrm{FJ}$ ' were silvery-grey in color with pointed tips. In contrast to this, the hybrid ' $\mathrm{CJ}$ ' and its father parent, subsp. cuspidata, showed brown undersides of the leaves with hooked tips.

The mean and range of leaf, fruit and endocarp in size were shown in Table 3. There were the differences in traits between two hybrids and their parents. Except for leaf length and width, all traits of father parent. O. europaea subsp. cuspidata, were lower than those of mother parents and two hybrids. Between two mother parent olive cultivars, each quantitative trait of 'Frantoio' was higher than that of 'Coratina', with the exception of endocarp length. Fruit and endocarp of two $F_{1}$ hybrids were between mother parent and father parent in size. Fruit length and endocarp length of ' $\mathrm{FJ}^{\prime}$ ' were higher than those of parents and another $\mathrm{F}_{1}$ hybrid, ' $\mathrm{CJ}$ '. The comparison between two $\mathrm{F}_{1}$ hybrids showed that leaf length and width, fruit width and endocarp width of ' $\mathrm{FJ}$ ' were lower than those of ' $\mathrm{CJ}$ '. 
In general, morphological description of olive cultivars involves characteristics of the tree, fruit, leaf and inflorescences, among others. Of these, endocarp characteristics are considered as the most discriminating and stable ones of strict genetic control, while other characteristics, such as those of the fruit, are more influenced by environmental conditions [37]. Moreover, endocarps may also be conserved for a long time, and they are easily exchanged among collections. For these reasons, the description of the endocarp has been frequently used to catalog olive cultivars [30,38-40].

\subsection{Parentage Analysis and Progeny Discrimination by SSR}

The six microsatellites appertaining to the series DCA [24], UDO [25] and EMO [26] were successfully amplified in all the studied five genotypes, two hybrids and their parents (Table 6). Five SSR loci showed polymorphisms between mother parents, 'Frantoio' and 'Coratina'. The microsatellite allelic profiles of two $\mathrm{F}_{1}$ hybrids were compared with those of their related parental lines because alleles at all SSR loci of offsprings were inherited from their parents. The inheritance of SSR alleles for 'FJ' and its parents revealed that those of 243bp and 253bp at DCA3 (Figure 2A), 141bp at DCA11 (Figure 2B) were inherited from 'Frantoio' and subsp. cuspidata, respectively. Similarly, the 172bp and 174bp at DCA18, $114 \mathrm{bp}$ and 120bp at UDO11, 130bp and 166bp at UDO19 were also inherited from 'Frantoio' and subsp. cuspidata, respectively. In the same way, another $\mathrm{F}_{1}$ hybrid ' $\mathrm{CJ}$ ' inherited SSR alleles from its parents, 'Coratina' and subsp. cuspidata. Two $\mathrm{F}_{1}$ hybrids ('FJ' and 'CJ') were confirmed as the offspring of their cited parents because their patterns of SSR alleles were successfully matched to their mother and father on the basis of the presence of parental-specific SSR alleles.

Table 6. SSR molecular markers of two $F_{1}$ hybrids and their parents.

\begin{tabular}{|c|c|c|c|c|c|c|}
\hline \multirow{2}{*}{ Hybrid/Cultivars } & \multicolumn{6}{|c|}{ SSR Locus } \\
\hline & DCA3 & DCA11 & DCA18 & UDO11 & UDO19 & EMO90 \\
\hline subsp.cuspidata (or) & $239 / 253$ & $131 / 141 / 244$ & $172 / 196$ & $112 / 114$ & $130 / 130$ & $182 / 186$ \\
\hline 'Frantoio' () & $237 / 243$ & $131 / 141$ & $174 / 176$ & $110 / 120$ & $130 / 166$ & $186 / 192$ \\
\hline 'Coratina' (우) & $239 / 243$ & $131 / 141$ & $174 / 178$ & $110 / 126$ & $112 / 112$ & $186 / 192$ \\
\hline 'FJ' ( $\mathrm{F}_{1}$ hybrid) & $243 / 253$ & $141 / 141$ & $172 / 174$ & $114 / 120$ & $130 / 166$ & $186 / 186$ \\
\hline ' $\mathrm{CJ}$ ' ( $\mathrm{F}_{1}$ hybrid $)$ & $243 / 253$ & $131 / 141$ & $172 / 178$ & $112 / 126$ & $112 / 112$ & $182 / 186$ \\
\hline
\end{tabular}

The SSR markers in this study have been previously used in the genotyping of olive cultivars 'Frantoio' and 'Cortina' [35,39]. In theory, SSR markers should produce the same profile regardless of the analysis system, the conditions or the equipment used, so that the data are comparable. Nevertheless, it has been shown that SSR profiles may differ between different laboratories and that these differences may be equally attributable to the equipment and/or the technical ability of the worker [41]. In this study, olive cultivars 'Frantoio' and 'Coratina' were detected by the alleles of 174/176 bp and 174/178 bp in DCA 18. There was a $3 \mathrm{bp}$ allele difference between the alleles in DCA 18, which produced 177/179 bp and 177/181 bp of 'Frantoio' and 'Coratina' in the previously published data [5,39]. These discrepancies may be explained by experimental errors or sizing discrepancies, as has been previously observed in similar studies of olive cultivar identification for the standardization of a set of microsatellite markers [41]. 
A
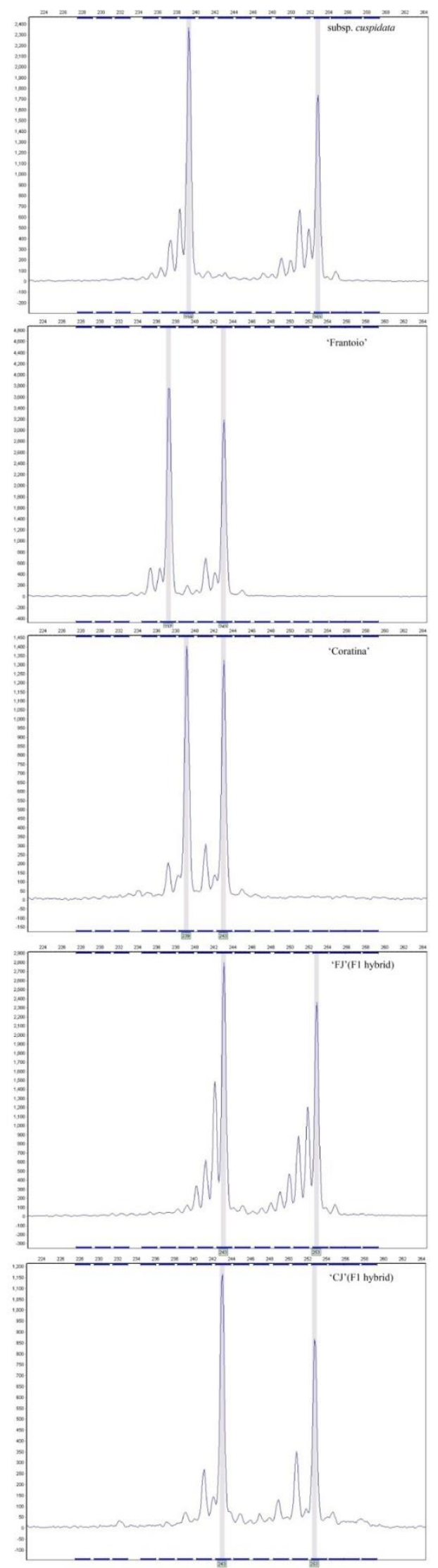

B
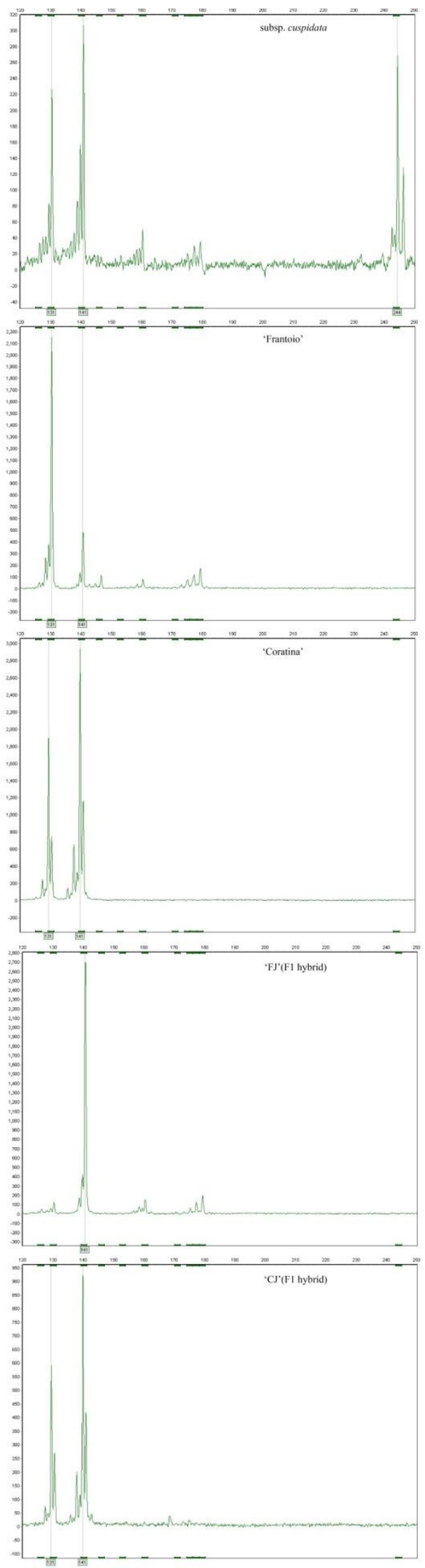

Figure 2. Allelic profiles at SSR locus DCA3 (A) and DCA 11(B) of DNAs from O. europaea subsp. cuspidata, 'Frantoio', 'Coratina' and two $\mathrm{F}_{1}$ hybrids, ' $\mathrm{FJ}$ ' and ' $\mathrm{CJ}$ '. in the line. 


\subsection{DNA Sequence Alignment of Progenies and Their Parents by SCNL}

Besnard and El Bakkali (2014) investigated the sequence variation at five nuclear single-copy genes in 41 native and invasive accessions of the Mediterranean and African olive subspecies, including in the wild individuals from the native range (13 cuspidata and 17 europaea) and 11 trees from the invasive range [42]. Their data confirm that four invasive individuals are early-generation hybrids, which indicate that sequences of singlecopy genes are powerful enough to detect introgression from a subspecies to another. In the study, three SCNLs (SWH1, SWH5 and SWH6) [29] were used for amplification of single-copy genes in the two progenies and their parents. After that, PCR products were sequenced and performed alignment analysis on the effective data (Figure 3). Results of the sequence comparison showed that there were a total of 15 different base sites between two progenies, ' $\mathrm{FJ}$ ' and ' $\mathrm{CJ}$ ', among which there were the number of different base sites, nine in SWH1 (Figure 3D), two in SWH5 (Figure 3E) and four in SWH6 (Figure 3F) amplified sequences. In addition, the 5th, 68th, 135th, 452nd, 520th and 719th sites in SWH1 amplified sequence (Figure 3D) and the superposed 44th and 60th sites in SWH5 amplification sequence (Figure 3E) confirmed that ' $\mathrm{CJ}$ ' was a true hybrid of 'Coratina' and subsp. cuspidata. Similarly, the superposed bases at the 44th, 60th, 334th, 336th and 431st base sites in the SWH5 sequence (Figure 3E) and the $75^{\text {th }}$ and 324th in SWH6 sequence (Figure 3F) indicated that 'FJ' was the true hybrid between 'Frantoio' and subsp. cuspidata.

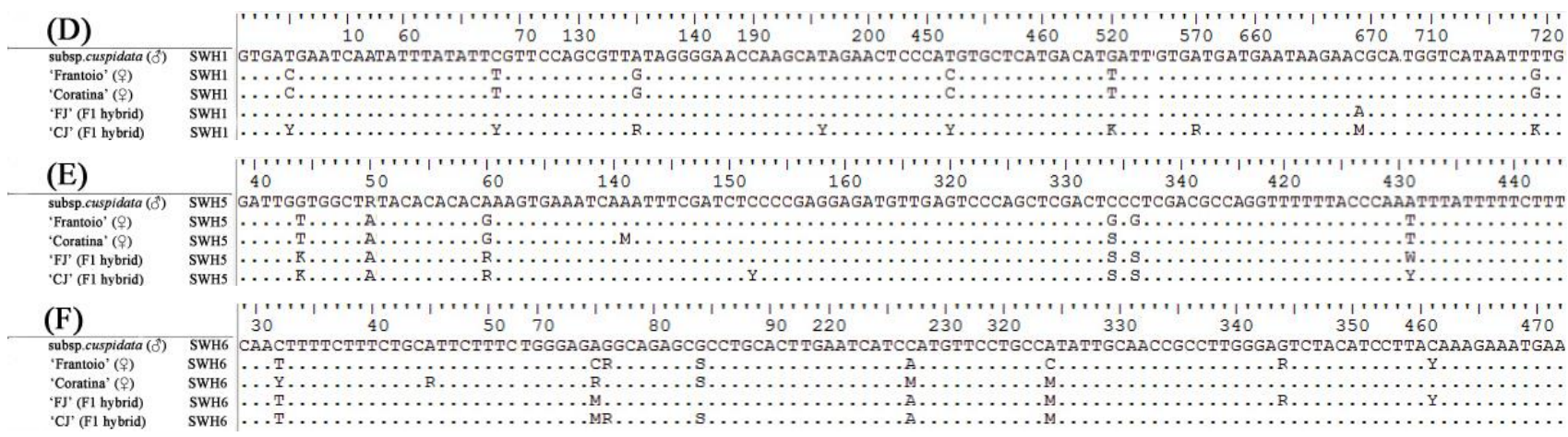

Figure 3. DNA sequence alignment of the PCR product amplified by SCNLs, SWH1 (D), SWH5 (E) and SWH6 (F) with parents (subsp. cuspidata, 'Frantoio', 'Coratina') and two $\mathrm{F}_{1}$ hybrids ('FJ' and 'CJ').

A genomic approach based on genotyping by sequencing (GBS) is promising and may soon allow the investigation of patterns of differentiation and admixture over the whole olive complex [42]. In fact, the utility of single-copy gene sequences in olive population genomic and phylogenetic studies would provide more integrated and adequate information for phylogenetic and population-based studies, improving efficient discrimination during species identification and resolving the phylogenetic relationships and cultivar identification.

\section{Conclusions}

Five samples composed of two olive cultivars introduced from Italy, subsp. cuspidata from southern China and two $F_{1}$ hybrids obtained from two genetic combinations were investigated morphologically, measuring both qualitative and quantitative traits of leaf, fruit and endocarp and at the molecular level by SSR markers and SCNLs. A significant difference in morphological traits was found between two progenies and their parents, olive cultivars as the mother and subsp. cuspidata as the father. The hybrid ' $\mathrm{CJ}$ ' and its father parent, subsp. cuspidata, showed brown undersides of the leaves with hooked tips. Fruit and endocarp two hybrids were between the mother parent and father parent in size. Two $F_{1}$ hybrids were confirmed as offspring of their cited parents because their patterns of SSR alleles were successfully matched to their mother and father on the basis of the presence of parental-specific SSR alleles. Results of the sequence alignment with three 
SCNLs showed that there were a total of 15 different base sites between two progenies, and their amplified sequences indicated that two progenies were the true hybrid between olive cultivars and subsp. cuspidata.

Author Contributions: Conceptualization, J.L., J.Z.; methodology, J.L., X.J., Z.W., Y.Z.; investigation, J.L., X.J.; resources, J.L., Z.W.; data curation, J.L., Z.W., Y.Z.; writing—original draft preparation, J.L., X.J.; writing-review and editing, Z.W., Y.Z; supervision, J.Z. All authors have read and agreed to the published version of the manuscript.

Funding: This research was funded by Special Project of Tree Breeding and Cultivation Key Laboratory of RIF (no. ZDRIF201702), the National Nonprofit Institute Research Grant of the Chinese Academy of Forestry (no. CAFYBB2017ZA004-5) and the National Key Research and Development Program (no. 2019YFD1000602).

Conflicts of Interest: The authors declare no conflict of interest.

\section{References}

1. Haouane, H.; El Bakkali, A.; Moukhli, A.; Tollon-Cordet, C.; Santoni, S.; Oukabli, A.; El Modafar, C.; Khadari, B. Genetic structure and core collection of the World Olive Germplasm Bank of Marrakech: Towards the optimised management and use of Mediterranean olive genetic resources. Genetica 2011, 139, 1083-1094. [CrossRef]

2. Belaj, A.; Dominguez-García, M.D.C.; Atienza, S.G.; Urdíroz, N.M.; De La Rosa, R.; Satovic, Z.; Martín, A.; Kilian, A.; Trujillo, I.; Valpuesta, V.; et al. Developing core collection of olive (Olea europaea L.) based on molecular markers (DArTs, SSRs, SNPs) and agronomic traits. Tree Genet. Genomes 2012, 8, 365-378. [CrossRef]

3. Díez, C.M.; Imperato, A.; Rallo, L.; Barranco, D.; Trujillo, I. World-wide core collection of olive cultivars based on simple sequence repeatand morphological markers. Crop Sci. 2012, 52, 211-221. [CrossRef]

4. Besnard, G.; Khadari, B.; Navascués, M.; Fernández-Mazuecos, M.; El Bakkali, A.; Arrigo, N.; Baali-Cherif, D.; de Caraffa, V.B.; Santoni, S.; Vargas, P.; et al. The complex history of the olive tree: From late quaternary diversification of mediterranean lineages to primary domestication in the northern levant. Proc. R. Soc. Lond. Ser. B 2013, 280, 20122833. [CrossRef] [PubMed]

5. Mousavi, S.; Mariotti, R.; Bagnoli, F.; Costantini, L.; Cultrera, N.G.M.; Arzani, K.; Pandolfi, S.; Vendramin, G.G.; Torkzaban, B.; Hosseini-Mazinani, M.; et al. The eastern part of the Fertile Crescent concealed an unexpected route of olive (Olea europaea L.) differentiation. Ann. Bot. 2017, 119, 1305-1318. [CrossRef] [PubMed]

6. Besnard, G.; Terral, J.-F.; Cornille, A. On the origins and domestication of the olive: A review and perspectives. Ann. Bot. 2018, 121, 385-403. [CrossRef]

7. Díez, C.M.; Trujillo, I.; Martinez-Urdiroz, N.; Barranco, D.; Rallo, L.; Marfil, P.; Gaut, B.S.; Ruiz, P.F.M. Olive domestication and diversification in the Mediterranean Basin. New Phytol. 2015, 206, 436-447. [CrossRef] [PubMed]

8. Kaniewski, D.; van Campo, E.; Boiy, T.; Terral, J.; Khadari, B.; Besnard, G. Primary domestication and early uses of the emblematic olive tree: Palaeo botanical, historical and molecular evidences from the Middle East. Biol. Rev. 2012, 87, 885-899. [CrossRef] [PubMed]

9. Rallo, L.; Barranco, D.; Díez, C.M.; Rallo, P.; Suárez, M.P.; Trapero, C.; Pliego-Alfaro, F. Strategies for olive (Olea europaea L.) breeding: Cultivated genetic resources and crossbreeding. In Advances in Plant Breeding Strategies: Fruits; Al-Khayri, J., Jain, S., Johnson, D., Eds.; Springer: Cham, Switzerland, 2018.

10. Lavee, S.; Avidan, B.; Ben-Ari, G. Trends in breeding new olive varieties in Israel for quality and economic management. Agric. Sci. 2014, 5, 701-709. [CrossRef]

11. Hannachi, H.; Sommerlatte, H.; Breton, C.; Msallem, M.; El Gazzah, M.; Ben El Hadj, S.; Bervillé, A. Oleaster (var. sylvestris) and subsp. cuspidata are suitable genetic resources for improvement of the olive (Olea europaea subsp. europaea var. europaea). Genet. Resour. Crop Evol. 2008, 56, 393-403. [CrossRef]

12. Klepo, T.; De La Rosa, R.; Satovic, Z.; León, L.; Belaj, A. Utility of wild germplasm in olive breeding. Sci. Hortic. 2013, 152, 92-101. [CrossRef]

13. De La Rosa, R.; Klepo, T.; Arias-Calderón, R.; Toumi, A.; Domínguez-García, M.; Leon, L.; Belaj, A.; Mariotti, R.; Baldoni, L.; Satovic, Z.; et al. Current status of conservation, evaluation and usefulness of wild olive germplasm. Acta Hortic. 2014, 1057, 515-519. [CrossRef]

14. Belaj, A.; León, L.; Satovic, Z.; de la Rosa, R. Variability of wild olives (Olea europaea subsp. europaea var. sylvestris) analyzed by agromorphological traits and SSR markers. Sci. Hortic. 2011, 129, 561-569. [CrossRef]

15. Klepo, T.; Toumi, A.; De La Rosa, R.; León, L.; Belaj, A. Agronomic evaluation of seedlings from crosses between the main Spanish olive cultivar 'Picual' and two wild olive trees. J. Hortic. Sci. Biotechnol. 2014, 89, 508-512. [CrossRef]

16. León, L.; De La Rosa, R.; Velasco, L.; Belaj, A. Using wild olives in breeding programs: Implications on oil quality composition. Front. Plant Sci. 2018, 9, 232. [CrossRef] [PubMed]

17. León, L.; Díaz-Rueda, P.; Belaj, A.; De la Rosa, R.; Carrascosa, C.; Colmenero-Flores, J. Evaluation of early vigor traits in wild olive germplasm. Sci. Hortic. 2020, 264, 109157. [CrossRef] 
18. Díaz-Rueda, P.; Franco-Navarro, J.D.; Messora, R.; Espartero, J.; Rivero-Núñez, C.M.; Aleza, P.; Capote, N.; Cantos, M.; GarcíaFernández, J.L.; De Cires, A.; et al. SILVOLIVE, a germplasm collection of wild subspecies with high genetic variability as a source of rootstocks and resistance genes for olive breeding. Front. Plant Sci. 2020, 11, 1-15. [CrossRef] [PubMed]

19. Cáceres, M.E.; Ceccarelli, M.; Pupilli, F.; Sarri, V.; Mencuccini, M. Obtainment of inter-subspecific hybrids in olive (Olea europaea L.). Euphytica 2014, 201, 307-319. [CrossRef]

20. Lavee, S. Evaluation of the need and present potential of olive breeding indicating the nature of the available genetic resources involved. Sci. Hortic. 2013, 161, 333-339. [CrossRef]

21. Lavee, S.; Zohary, D. The potential of genetic diversity and the effect of geographically isolated resources in olive breeding. Isr. J. Plant Sci. 2011, 59, 3-13. [CrossRef]

22. Green, P.S. A revision of Olea, L. (Oleaceae). Kew Bull. 2002, 57, 91-140. [CrossRef]

23. Trapero, C.; Rallo, L.; López-Escudero, F.J.; Barranco, D.; Díez, C.M. Variability and selection of Verticillium wilt resistant genotypes in cultivated olive and in the Olea genus. Plant Pathol. 2014, 64, 890-900. [CrossRef]

24. Shi, Z.M.; Luo, F.S.; Li, Y.; Yang, F.Y.; Xie, K.M.; Yang, W.M. Study on the rootstock (Olea ferruginea) for grafting olive. Acta Bolanica Yunnanica 1991, 13, 65-74. (In Chinese)

25. Arias-Calderón, R.; Rodríguez-Jurado, D.; León, L.; Bejarano-Alcázar, J.; De La Rosa, R.; Belaj, A. Pre-breeding for resistance to Verticillium wilt in olive: Fishing in the wild relative gene pool. Crop Prot. 2015, 75, 25-33. [CrossRef]

26. Wei-Ying, H. Introduction of olive trees in China. Sci. Silvae Sin. 1981, 17, 78-83. (In Chinese)

27. Pan, L.; Li, Y.J.; Ma, T.; Wu, T.; Ning, D.L. SSR Identification of authenticity of interspecific hybrids between Olea europaea $\times$ cuspidata. Mol. Plant Breed. 2019, 17, 2279-2284. (In Chinese)

28. Niu, E.; Jiang, C.; Wang, W.; Zhang, Y.S.Z. Comparative study on the growth and morphology of new olive variety 'Jinyefoxilan' and its parents. Nanfang Yuanyi South. Hortic. 2015, 26, 1-3. (In Chinese)

29. Tian, X.; Yang, W.; Ting, M.; Na, H.; Yongjie, L.; Delu, N. Preliminary study on the characteristics of hybrid of Olea europaea L. J. West China For. Sci. 2020, 49, 130-135. (In Chinese)

30. Barranco, D.; Cimato, A.; Fiorino, P.; Rallo, L.; Touzani, A.; Castaneda, C.; Serafin, F.; Truijillo, I. World Catalogue of Olive Varieties; International Olive Council: Madrid, Spain, 2000.

31. de la Rosa, R.; James, C.M.; Tobutt, K.R. Isolation and characterization of polymorphic microsatellites in olive (Olea europaea L.) and their transferability to other genera in the Oleaceae. Mol. Ecol. Notes 2002, 2, 265-267. [CrossRef]

32. Sefc, K.M.; Lopes, M.S.; Mendonça, D.; Santos, M.R.D.; Machado, M.L.D.; Machado, A.D. Identification of microsatellite loci in olive (Olea europaea) and their characterization in Italian and Iberian olive trees. Mol. Ecol. 2000, 9, 1171-1173. [CrossRef]

33. Cipriani, G.; Marrazzo, M.T.; Marconi, R.; Cimato, A.; Testolin, R. Microsatellite markers isolated in olive (Olea europaea L.) are suitable for individual fingerprinting and reveal polymorphism within ancient cultivars. Theor. Appl. Genet. 2002, 104, 223-228. [CrossRef]

34. de la Rosa, R.; Belaj, A.; Muñoz-Mérida, A.; Trelles, O.; Ortíz-Martín, I.; González-Plaza, J.J.; Valpuesta, V.; Beuzón, C.R. Development of EST-derived SSR markers with long-core repeat in olive and their use for paternity testing. J. Am. Soc. Hortic. Sci. 2013, 138, 290-296. [CrossRef]

35. Jihène, D.; Mahdi, F.; Breton, C.M.; Msallem, M. Characterization of olive progenies derived from a Tunisian breeding program by morphological traits and SSR markers. Sci. Hortic. 2018, 236, 127-136.

36. Shao, W.H. Study on Molecular Identification and Genetic Evaluation of Olive Cultivars in China. Ph.D. Thesis, Chinese Academy of Forestry, Beijing, China, 2019.

37. Koubouris, G.C.; Avramidou, E.; Metzidakis, I.T.; Petrakis, P.V.; Sergentani, C.K.; Doulis, A.G. Phylogenetic and evolutionary applications of analyzing endocarp morphological characters by classification binary tree and leaves by SSR markers for the characterization of olive germplasm. Tree Genet. Genomes 2019, 15, 26. [CrossRef]

38. D'Imperio, M.; Viscosi, V.; Scarano, M.T.; D'Andrea, M.; Zullo, B.A.; Pilla, F. Integration between molecular and morphological markers for the exploitation of olive germoplasm (Olea europaea). Sci. Hortic. 2001, 130, 229-240. [CrossRef]

39. Trujillo, I.; Ojeda, M.A.; Urdiroz, N.M.; Potter, D.; Barranco, D.; Rallo, L.; Diez, C.M. Identification of the worldwide olive germplasm bank of Córdoba (Spain) using SSR and morphological markers. Tree Genet. Genomes 2013, 10, 141-155. [CrossRef]

40. Fendri, M.; Trujillo, I.; Trigui, A.; Rodríguez-García, M.I.; Ramírez, J.D.A. Simple sequence repeat identification and endocarp characterization of olive tree accessions in a Tunisian germplasm collection. Hortscience 2010, 45, 1429-1436. [CrossRef]

41. Doveri, S.; Gil, F.S.; Díaz, A.; Reale, S.; Busconi, M.; Machado, A.D.C.; Martín, A.; Fogher, C.; Donini, P.; Lee, D. Standardization of a set of microsatellite markers for use in cultivar identification studies in olive (Olea europaea L.). Sci. Hortic. 2008, 116, 367-373. [CrossRef]

42. Besnard, G.; El Bakkali, A. Sequence analysis of single-copy genes in two wild olive subspecies: Nucleotide diversity and potential use for testing admixture. Genome 2014, 57, 145-153. [CrossRef] 